\title{
Imitación, aprendizaje y la fundación de una nueva organización: la creación del Consejo Mexicano de promoción Turística
}

\section{Imitation, learning and the founding of a new organization: the creation of the Mexican board of tourist promotion}

\author{
Jorge E. Culebro-Moreno* \\ Steinar AskviK**
}

\begin{abstract}
In 1999 the Mexican Board of Tourist Promotion (MBTP) was created as a representative organism of the Mexican government with the view of supporting the promotion of the national touristic industry, and its creation may be seen as a result of a series of mechanisms to learn public administration. In this sense, this article tries in researching how the creation of MBTP can be interpreted as an instance of said critical processes of learning associated to the establishment of a new public organization. The approach is focused on the process of creating a new public agency in a society undergoing transformation, according to an institutional perspective on the basis of the normative, cognitive and regulations institutional spheres.
\end{abstract}

Keywords: institutional learning; institutional spheres; administrative reform; transference of public policies.

\section{Resumen}

En 1999 se formó el Consejo Mexicano de Promoción Turística (cmpt) como un organismo representativo del gobierno mexicano, con el objetivo de apoyar la promoción de la industria nacional del turismo, y su creación se puede ver como resultado de una serie de mecanismos de aprendizaje de la administración pública. En este sentido, este artículo intenta investigar cómo la creación del cmpt se puede interpretar como un ejemplo de dichos procesos críticos de aprendizaje asociados al establecimiento de una nueva organización pública. El enfoque se centra en el proceso de crear una nueva agencia pública en una sociedad en transformación, de acuerdo con una perspectiva institucional con base en los ambientes institucionales normativo, cognitivo y regulatorio.

Palabras clave: aprendizaje institucional, ambientes institucionales, reforma administrativa, transferencia de políticas públicas.

* Universidad Autónoma Metropolitana, Cuajimalpa, México. Correo-e: jcmoreno@correo.cua. uam.mx. jorge_culebro@hotmail.com

** University of Bergen, Noruega. Correo-e: steinar.askvik@aorg.uib.no. 


\section{Introduction}

The founding of a new organization may be seen as an attempt to design "better ways of doing things that are not easily done within existing social arrangements" (Stinchcombe, 1965: 146). It may be conceptualized as a learning process where the actors involved struggle to acquire knowledge about what will be the critical tasks of the new organization, and how its members will deal with the tasks that are identified as critical. Knowledge can be acquired through imitation, by copying the practices of other organizations in a similar situation, or by learning from direct experience in a step-by-step fashion. Imitation implies some kind of vicarious learning where the learning organization is able to draw on the lessons made by other organizations, e.g. by copying certain policies, programs, rules and routines that are considered to be beneficial. Learning from direct experience refers to processes of trial-and-error where organizations experiment with different ways of doing things and on the basis of experience adopt procedures that are considered more successful.

The learning associated with founding a new organization is most likely to be conceptualized as an open process that may take a number of different directions. Nevertheless, an organization is always founded within a specific social structure that tends to leave its imprints on the new organization. Organizations reflect social relations, i.e. constellations of actors, interests and values, and they mirror the resources and knowledge that actors may access. They adapt to cognitive, moral and regulatory expectations presented by affected groups of stakeholders and they frequently have to demonstrate that their practices are compatible with dominant views on how legitimate organizations ought to act.

In the present article, we investigate how the creation of the Mexican Board of Tourist Promotion (MBTP) can be interpreted as an example of such critical learning processes associated with establishing a new public organization. In particular, we explore the critical conditions of policy learning and implementation, and the focus is upon the process of founding a new public agency in a transforming society. We explore the creation of The Mexican Board of Tourist Promotion in order to understand the dynamics of organizational change and learning in the Mexican context.

The MBTP was set up in 1999 as a representative body by the Mexican Government in order to assist the national tourist industry in promoting tourism. Its creation may be seen as an instance of vicarious learning in so far as the organization model of the Board was based on similar bodies that existed in a number of other countries, and known to be successful in the tourism sector. The organizational model included representation by private as well as public actors on the Board, and it implied some kind 
of public-private hybrid organizational form (Hodge and Greeve 2007), which gave the body an autonomous status in relation to the federal bureaucracy. Nevertheless, the explanatory power of vicarious learning, as a way of learning through copying from other organizations, can only to a very limited extent explain the subsequent development of the мвтр. It seems more relevant to interpret the development as a learning process where the new organization has to deal with a number of administrative, financial, legal and cultural constraints represented by its task environments, and where the formal structure copied from abroad has a very limited impact on the activities which are eventually put into place.

In relation to the methodology considerations, ${ }^{1}$ this investigation derives from a broader research on organizational learning and the adoption of New Public Management in the Mexican government, which involved a collection of interviews with public servants at different levels of the public administration in distinct periods of time from 1999 to 2001. At the ministerial level interviews included public officials from the Ministry of Finance, the Ministry of Comptrollership and with the Ministry of Tourism. In addition, a set of interviews were conducted with the directors of the Board of Tourism, particularly two with the General Director of Administration, four with the General Director of Human Resources, two with the Vice-director of Finance and two with the Vicedirector of Performance Indicators. The length of the interviews was approximately two hours, either inside the Board or outside, for instance in restaurants so as to have a more flexible environment. The research also involved an extensive review of documents from three main sources: 1) from the government at the federal level; 2) from the Board of Tourism; and 3) from the private tourism sector. Besides, the research involved an analysis of the legal framework under which the Ministry of Tourism and the мвтр operate. During the investigation process, interviews have diverse purposes; one the one hand, they served to confirm and expand the information provided by the documents, and on the other, meetings with public servants shed light on the details of the MBTP and allowed contrasting the official discourse. Most of the officials played the role of key informants due to their closeness and trustworthiness.

\footnotetext{
${ }^{1}$ The article departs from the idea that a great amount of validity in conducting case-studies is constructed through systematic inferences, as well as depending upon the procedures carried out during the research process. These strategies are built with the purpose of revealing the complex and dynamic processes that occur inside and outside the organizations, not of evaluating or measuring specific results. Under this perspective, cases are considered as specific theoretical constructs where there is a continuous interaction between ideas and evidence. See for example: Brower et al. (2001), Cresswell (1994), Guba and Lincoln (1994) Ragin and Becker (1997), Walton (1997), Ragin (1997), Little (1991), Hollis (1999), Wievorka (1997).
} 
The article is divided into the following parts. Firstly, we will present the theoretical framework, more specifically a model based on Richard Rose's ideas on how lessons are drawn from abroad, and the institutional perspective of W. Richard Scott. Then, we explore the case of the founding and implementation of the MвтP. Finally, we will discuss the critical conditions of policy learning and implementation in Mexico. ${ }^{2}$

\section{Lesson-drawing, organizational learning and institutional context}

We want to interpret the establishment of the MBTP as an example of lesson-drawing in the public sector of Mexico, and we ask how the institutional context impacts on the process of its implementation and formation (Christensen and Laegreid 2001, 2007). Inspired by Rose (1993), Dolowitz and Marsh (2000) have presented a more general model of said processes of policy transfer where the knowledge on policy programs in one context is used to develop similar programs in another context. According to their framework various instances of policy transfer may be classified on the basis of seven questions: Why do actors engage in policy transfer? Who are the key actors involved in policy transfer processes? What is transferred? Where are lessons drawn from? Which are the different degrees of transfer? Which restricts or facilitates the policy transfer process? How is the process of policy transfer related to policy success or policy failure? These are interesting questions that direct attention to the various types of policy transfer that might exist. For instance, whether policy transfer is coercive or voluntary, or whether it is initiated by politicians or bureaucrats, may have consequences on how such processes unfold, and whether outcomes are successful or not.

In particular, we want to emphasize the distinction between lessondrawing and lesson implementation in policy transfer. This distinction tends to become somewhat blurred in the model by Dolowitz and Marsh, and it is unclear when a policy has been transferred. For example, is it when a lesson has been drawn and a policy has been formally adopted, or is it when it has been executed and put into practice? As the literature

\footnotetext{
${ }^{2}$ In relation with the concepts of learning and institutional learning, it is important to mention that the article is not focused on considering organizational learning as a result, it is conceived however as a process in which it is intended to study its consequences in terms of policy learning. The purpose of the article is to draw some conclusions concerning the creation and development of the мвтр by using different theoretical models in the context of administrative reforms, and not to verify whether the organization has learned. For the sources of the terms of learning and institutional learning see for example: Greenwood et al. (2008), Powell and Colvas (2008), Leicht and Fenner (2008), Hinings and Tolbert (2008), Haunschild and Chandler (2008), March and Olsen (2006), Heclo (2006), Egeberg and Laegreid (1999), Peters (1999), Laegreid and Roness (1998), Askvik and Tveten (2000), Christensen and Boin (2008).
} 
on policy implementation has documented the process from policy adoption to policy implementation, it may significantly transform the content of a policy reform and what actually takes place in practice when a program is executed (Christensen and Laegreid, 2007). We find the position of Richard Rose (1993) clearer in this respect, in so far as he restricts the concept of lesson-drawing for the process of developing, not implementing, policy prescriptions. He identifies four analytical stages of lessondrawing: 1) searching for a relevant program to imitate; 2) abstracting a cause-and-effect model; 3) creating a lesson (i.e. a new program to be implemented); 4) carrying out a prospective evaluation. In particular, under stage 3, Rose points out that creating a lesson may take different forms: copying, adapting, making a hybrid or synthesizing, inspiring. To copy means that the lesson drawn is very similar to the prototype, while adaptation entails that contextual adjustments are made when the new program is designed. Making a hybrid or synthesizing imply that components from several programs are combined; whilst inspiring merely denotes that policymakers are stimulated to think in novel ways.

These are activities that should take place prior to the implementation of a lesson that has been drawn. Rose sees his main contribution as normative, "to give guidance in drawing lessons" (p. xi), not to explain how learning occurs. In contrast with this, our focus is descriptive and explanatory since we want to understand how lesson-drawing actually takes place and in particular what happens when lessons are implemented (Ragin and Becker, 1992). We conceptualize the implementation mechanisms as processes of organizational learning and innovation where the organization develops new structures and routines in a step-by-step fashion. Even though a rough model of the new organization is provided through the lesson drawn prior to its implementation, many issues still have to be solved. Objectives may be formulated, and a formal structure may be in place. Yet, how to prioritize and concretize objectives are not normally specified in advance, and the formal structure of an organization can only to a very limited extent provide guidance for practical action. As noted by Aldrich in conjunction with a discussion of how communities of practice emerge: "Learning takes place at all levels in new organizations, with members collaborating in constructing a new meaning system" (1999: 144).

An important part of this learning is colored by the knowledge members have acquired through previous experience. The other source of such learning is direct experience as members interact to solve new tasks and discover through trial and error which actions are beneficial. Actions that produce satisfactory outcomes are repeated and tend to become routine. 
In our analysis we want to draw attention to how the institutional context impacts on lesson implementation in Mexico. For such a purpose we shall use the three pillars or supporting institutions of Scott (2001) to identify relevant characteristics of the institutional environments. The three pillars are the regulative, normative and cultural-cognitive elements of the social structures that make up the main institutions of a society. The regulative pillar encompasses the rules and laws that govern and constrain behavior and implies the capacity to establish rewards or punishments. The normative pillar refers to how dominant norms and values create expectations of what is socially desirable, that is to say the legitimate goals and objectives, as well as the means to pursue ends. The culturalcognitive pillar denotes the common conceptions that provide meaning to social relationships, in which routines are taken for granted. The use of the three pillars denotes the possibility to combine different disciplines into an integrated model of institution (Scott, 2001: 69). In consequences, learning is understood as the process through which rules and structures are transformed on the basis of interpretation of experience, and presumes that organizations possess history and values, where institutions are stable collection of practices embedded in structures of meaning. We assume that when a new organization is established such elements will influence how the organization evolves, and how stakeholders and members come to develop standardized ways of responding to the tasks and problems they confront. Thus, the Federal Constitution of Mexico and the legal system regulating its public administration will to a large extent determine what kind of formal structure a public agency may adopt or not, and who will have the authority to make changes, as well as set out regulations in terms of control and accountability. From the perspective of the normative pillar, characteristics of national culture will influence how organizational relationships tend to develop. When a new organization is established we may, for instance, hypothesize that the forms of patrimonialism and power distance (Hofstede, 1991), which traditionally characterize Mexican social relationships, will be reproduced. And cultural-cognitive elements will frame the dominant way of thinking about organization and management, i.e. what influential players define as appropriate organizational forms and management methods in the public sector of Mexico. 


\section{The case of the Mexican board of tourist promotion}

\subsection{Searching for an organization to imitate; learning through successful experiences}

The history of the founding of the Board might be traced back to the beginning of the Zedillo's administration (1995-2000) when the Mexican government launched a comprehensive reform program that included a reduction of public expenditure, downsizing and introducing private sector techniques into the public sphere. Before the creation of MBTP, the Ministry of Tourism entered into a modernization process that incorporated major changes in its formal structure, downsizing, reengineering and developing performance indicators. The initiative to reorganize the public promotion of the tourism came primarily from the General Office of Administrative Modernization, specifically the Advisor's Office as a part of the Head of the Administration of the Ministry of Tourism. The Advisor's Office was the unit in charge of carrying out the reform process inside the Ministry of Tourism and later it also became in charge of establishing the Board.

At the outset there was a general consensus, not only about the objectives and goals of the Ministry of Tourism, but also concerning the challenges that the Ministry had to face, which were brought onto the agenda by the Advisor's Office inside the Ministry. One such challenge was the reform process implemented by the Ministry of Finance and the Ministry of Comptrollership that impelled the Ministry of Tourism to be more efficient and seek new instruments to achieve its goals. Besides, there were reductions in the federal budget for tourist promotion; another major challenge referred to the difficulty of facing the competition to attract tourists from the international and national environment.

The creation of the Board can be understood as a reaction to the domestic and international environments around 1995. The Advisor's Office noted a significant lack of co-ordination among the main players in charge of advertising tourism activities. A diagnosis made at the beginning of Zedillo's administration and carried out by the Ministry of Tourism ${ }^{3}$ showed there was no clear and precise information regarding tourist markets, and the existence of several development strategies reflected an absence of coherence between the government and the private sector. Financial and human resources were wasted because of the scattered efforts to promote tourism. In addition there was a significant drop in the

${ }^{3}$ Ministry of Tourism, external diagnosis, unpublished. 
federal financial support for international tourist promotion due to the profound economic crisis Mexico suffered during 1995.

Three general features influenced the development of international tourism and the formation of the Board: Firstly, at the global level, technological change reduced transportation and telecommunications costs, and transformed commercial knowledge of tourist services and products; consequently the consumers' preferences changed and the management and marketing of the tourist agencies improved. Secondly, the globalization process made tourists become more informed about destinations and created more variety in tourist activities, and the circulation of new communication technologies provided a greater quantity of information. Thirdly, the growing competence in the tourism sector led to an increase in the quality of services provided, and the competitive pressures generated incentives to search out new products. In summary, the Mexican tourism sector faced a dynamic international context characterized by a strong market orientation where different countries adopted more and more competitive strategies to attract tourists.

In order to deal with this situation successful experiences from countries with a strong tradition of tourism were studied, in particular countries as France, Spain, Great Britain, Canada and Ireland. The countries in question were chosen partly because of some kind of ideological compatibility (Spain and France), and partly because they had a very successful reputation. The authorities at the Ministry of Tourism observed that at international level there was a tendency for establishing joint-autonomous organizations to strengthen the functions of public planning and co-ordination of tourism promotion. Such national tourism organizations were presided over by Executive Tourism Agency, with a wide participation of the private sector in the decision-making process. ${ }^{4}$

Hence, to a certain extent the starting point of the Board of Tourism was knowledge about the international context in which the Ministry of Tourism performed its activities. As one of the respondents noted:

By studying successful countries, we have realized that the growing international ability to attract tourists and economical resources is reproduced not only in budget increases to promote the leading tourist countries, but also in the creation of new forms of international promotion. ${ }^{5}$

The selected countries were all perceived to be successful touristic destinations and it appeared that in each country the tourism policy involved some kind of hybrid organ that combined representation from

\footnotetext{
${ }^{4}$ Interview, мвтр, Director of Human Resources.

${ }^{5}$ Interview, мBтP, General Director of Administration.
} 
both the private and public sectors. The mixture of players included participation from different government departments as well as from the tourism industry in the decision-making process. The institutional design of such tourist boards enabled a high degree of administrative autonomy and also allowed them to obtain financial resources from different sources, including support from the Central Government and contributions from the private sector through co-operative programs, which were not necessarily capital investments. Such agencies had commercial offices and marketing representations in most important international markets in order to operate advertising strategies with national and foreign private partners and to provide information. ${ }^{6}$

\subsection{Abstracting a cause-effect model; the lesson model}

According to the designers of the Board, the public tourist organizations studied in France, Spain, Great Britain, Canada and Ireland presented similar trends. Hence, the designers assumed that certain causal mechanisms were at work, which linked such organizations to a successful tourist policy. Firstly, it was noted by the Advisor's Office that the setting up of the Board required the participation of a variety of players from both public and private sectors in order to combine distinct experience and knowledge. Thus, the Board included actors from the public administration, such as the Federal Government through the Ministry of Tourism and Joint Funds, and the local Governments funds by means of the application of a lodging tax and using their own resources. The private sector included players from the tourism industry through co-operation programs with different levels of Government, commercial partners abroad, and chambers of commerce through their own resources and holding programs. ${ }^{7}$

Secondly, in the case of leadership, these organizations had a joint leadership to the extent that planning and decision-making processes were shared with Central, Regional and Local levels of government, ${ }^{8}$ as well as with the private sector. The organizational structures tended to be more participative, horizontal and consensual. As a result, such structures facilitated participation of the public and private sectors in the evaluation

${ }^{6}$ Ministry of Tourism, MвтP, Tourism in Mexico.

${ }^{7}$ Ministry of Tourism, MBтP (2000). Recognition of the Quality and Innovation in Public Administration; Innovation of the general process of national and international tourism promotion through the incorporation of a majority state-owned company called Consejo Mexicano de Promoción Turística, s.A. de c.v. Detailed Report, June.

${ }^{8}$ From a legal and formal perspective, Mexico is divided into three levels of Government: Federal, State and Municipal; however, for the purposes of the article and the focus of the study, we also refer to the central, regional and local level from economic and sociological point of view. 
of activities through institutional mechanisms of co-ordination. In general terms, the board of directors was composed of government and private sector representatives, such as those involved in the tourist activities of airlines, hotels and restaurants. The knowledge about promotion strategies came from three main sources: 1) from specialized technical committees; 2) from an outside advisory council; and 3) from special groups formed in international markets along with commercial partners abroad. ${ }^{9}$ The table below illustrates some of the similarities.

Thirdly, the organizations in question provided a number of experiences regarding how objectives and standard operation procedures were developed. According to officials from the General Sub-direction of Administration of the MBTP, strategic inductive planning models were frequently adopted by such organizations. Promotional activities were developed on the basis of comprehensive studies of different markets, and they would be targeted to the kind of tourist destination and product in question (e.g. beach, archaeology, golf, art, etc.) Generally, these organizations prepared work programs which spanned several years, with novel schemes linking multiple partners and covering different products and markets.

Fourthly, the economic aspects of the above mentioned tourist boards were also considered to be critical. An important characteristic was the variety of the financial resources. All the boards were financed with public resources; however, most of them also encouraged active participation of the private sector in the funding of their promotion strategies. Generally, they developed long-term financing plans, which in some cases were tied to the flow of tourist activity. In order to obtain more resources and homogenize these strategies, the councils in question tried to implement co-operative financing programs with the industry and commercial partners abroad. ${ }^{10}$

Fifthly, with reference to human resource development these organizations tended to recruit highly qualified personnel trained in the design of promotion programs and product development, as well as in giving advice to partners in marketing matters. The salaries of the personnel would be at a competitive level with the private sector in order to attract qualified personnel from private companies and to promote permanency and stability.

Finally, commercial offices abroad were located in the main markets and they tried to generate information to commercial partners about changing opportunities and threats in the markets and about potential competitors. They also promoted co-operative programs between the

\footnotetext{
${ }^{9}$ Ministry of Tourism, MвтP (2000), Labour Record, October 1999 to October 2000. MBтP, Institutional Program 1991-2001.

${ }^{10}$ Interview, MBTP, Director of Human Resources.
} 
national tourist board, domestic commercial actors, and potential foreign partners. In addition such offices abroad contributed to the integration of promotion strategies in the foreign markets. ${ }^{11}$

\subsection{Creating a lesson; the institutional design}

In accordance with the New Public Management trend, the creation of the board follows the design of a vertical and horizontal specialization, which implies the establishment of single-purpose organizations and structural devolution in search for greater autonomy (Roness, 2007). The Mexican Tourism Promotion Board was set up in April 1999, through a bill presented by the Tourism Commission of the Chamber of Representatives, aimed at changing the Federal Tourism Law. This bill demonstrated a high level of consensus in the political sphere and the law was approved unanimously, creating a new body whose purpose was to design and operate tourist promotion strategies nationally and internationally together with the Ministry of Tourism.

According to the Federal Tourism Law, the MBTP was composed of five arenas of governance: the General Assembly, the Board of Directors, the General Comptroller, the Statutory Auditor, the Director General, and the technical committees. The General Assembly was the supreme decision-making body composed of members from the public and private sectors. The Board of Directors was in charge of the administration of the board, as well being responsible for defining and co-coordinating the strategies and policies to be followed and for approving campaigns and plans. Since the Board comprised three levels of governance, plus representatives of the private sector and public officials from the Secretariat of Tourism, ${ }^{12}$ roles and relationships tended to blur and members shared the same type of knowledge.

\subsection{Implementing the MвTP lesson}

The configuration of the Board rendered a capacity to respond rapidly to market opportunities and pressures. It would operate through co-opera-

${ }^{11}$ Ministry of Tourism, MвтP (2000) Recognition of the Quality and Innovation in Public Administration; Innovation of the general process of national and international tourism promotion through hte incorporation of a majority state-owned company called Consejo Mexicano de Promoción Turística, s.A. de c.v. Detailed Report, June

${ }^{12}$ The Board of Directors was composed of twenty-nine members distributed as follows: Fifteen designated by the Federal Government; that is one from the Secretariat of Tourism; one from the Secretariat of Treasury and Public Debt; one from the National Tourism Promotion Fund; eight from the States, replaced every three years; four from tourist municipalities, replaced every three years. In addition, it had fourteen representatives from the private sector. 
tive programs between governmental agencies and tourist destinations, representatives of the national tourist industry, and commercial partners abroad. The idea was to unify energies and resources in a common program for the development and promotion of tourist products. Thus, national tourism organizations were seen as commercial and market offices rather than as public agencies; and their principal function was to carry out the promotion strategies and look for co-operative arrangements with private, domestic and foreign partners. ${ }^{13}$

At the organizational level, the formulation of the mission and vision of the Board revealed a great deal of influence from international experience. The Board's mission emphasized the dynamics of the context in which the Board had to perform its activities. It highlighted the competitiveness of the market and focused its operation on the promotion of destinations. While the vision of the Board stressed the importance of collaboration between the private and the public sector to promote Mexico's tourist destinations. ${ }^{14}$

Concerning administration and decision-making, the Director General was the executive organ of the General Assembly and the Board of Directors. The Specialized Technical Committees operated as a body that advised the Board of Directors on market and product strategy issues, marketing programs and evaluation of management performance. Learning within the Board depended upon on the nature of the knowledge and the information available in each section of the МвтP, and the challenge consisted of transforming tacit knowledge into explicit knowledge through the Director General and operational areas.

When it comes to the organizational structure, two aspects stand out: firstly, the designers of the MBTP wanted to create a climate of closeness, particularly in the departments of Marketing and Promotion. Secondly, two broad types of ad hoc units were set up: one consisting of experts to produce information about the context in which the MBTP performed its activities; another type of ad-hoc units had more administrative functions. A highly dynamic and complex context encouraged the reduction of hierarchical levels and encouraged co-ordination through the workprocess and informal communication. Apart from the internal comptroller, managers and staff expert in tourism promotion mainly performed the most important MBTP activities. Strategic and relevant decisions were made at the upper levels of the Board. The Board appeared to be a small

\footnotetext{
${ }^{13}$ ST, MBTP, Induction Manual.

${ }^{14}$ The Mission was stated as follows: To combine the effort of all tourist industry organisations in order to promote Mexican tourist products and destinations in Mexico and abroad in order to increase Mexico's competitiveness. The Vision was defined as: To be a leading tourism promotion organisation that encourages the involvement of various organisations in the tourist industry, ST, MBTP, Strategic Plan.
} 
and rather simple structure, and it had an automated technical system to process information and generate knowledge.

The fact that the Board was created as a majority state-controlled enterprise had two main implications; ${ }^{15}$ as a partially state-owned enterprise the Board was strongly regulated and shared regulations that governed private companies such as General Corporation and Partnership Law, the Commercial Code, Fiscal Code, Commercial Bankruptcy Law. These laws regulate the establishment, operation, functioning and dissolution of private companies. In other words, authorities and personnel of the Board had to operate and to function like any other private enterprise. At the same time the Board had to comply with public law, such as the Organic Law of Federal Public Administration, the Federal Law of State-Owned Companies, and norms and regulations provided by the Secretariat of Treasury and Public Debt and the Secretariat of Comptrollership and Administrative Development. Accordingly, since the Board had to respond to regulations, both in the private as well as in the public sector, a special office from the Ministry of Comptrollership was installed inside the Board, and for the private partners the Assembly appointed statutory auditors.

Its sources of financing were much more diverse and heterogeneous than regular public agencies. They came from: 1) annual budgetary transfers from the Federal Government; 2) voluntary contributions from the private sector; 3) voluntary contributions from the state and city governments as well as partial state-controlled bodies; 4) co-operative programs; 5) members' contributions and membership fees; and 6) the мвтр was entrusted to engage in commercial activities that could generate additional funds. ${ }^{16}$

The establishment of the Board had to cope with a fundamental tension between the formulation of rational and logical long-term action strategies, and the short-term, spontaneous responses to changes in its complex and dynamic environments. A set of organizational routines was developed and they were built on the concept of promotion, which was divided into four stages: 1) induction, 2) co-ordination, 3) strategic planning and 4) execution. The induction stage included the involvement of the different levels of government and representatives of the domestic industry as well as foreign partners, in co-operative agreements. The coordination stage implied the creation of institutional mechanisms to integrate the different units of the Board like the Board of Directors, Specialized Technical Committees, Product Clubs and External Advisors Committees. ${ }^{17}$ The third stage covered strategic planning, in particular

\footnotetext{
${ }^{15}$ Interviews, MBTP, General Director of Administration, mbtp, Director of Human Resources.

${ }^{16}$ ST, MBTP, Marketing Plan.

${ }^{17}$ ST, MBTP, Institutional Program 1991-2001.
} 
activities to gather and process information in order to develop a marketing plan that would integrate promotion, market studies, advertising, public relation and direct marketing. ${ }^{18}$

For the authorities of the MBTP strategic planning became the most important tool to achieve its objectives, and as a result of this the Board developed its 1999-2001 Institutional Program where objectives and lines of action were explicitly linked in a logical framework. The strategic plan implied a clear focus on results and customer satisfaction and how to measure performance. This plan also attempted to convert the Board into a professional institution with an agile, flexible structure that would make it possible to respond quickly to opportunities and changing circumstances in the market, as well as to achieve transparency concerning programs and the intensive use of information technology. ${ }^{19}$

The Board attempted to establish a Performance Evaluation System as a logical response to the results oriented strategy. ${ }^{20}$ This system was conceived not only as review of activities, but also as a monitoring of results and as an evaluation instrument. Namely, the organization tried to link activities and results with mission and vision through performance indicators. The construction of the indicators allowed for quantifying objectives and their achievement, they established commitments, detected and prevented deviations from the goals and evaluated the attainment of objectives. ${ }^{21}$

The Board defined various types of indicators, for example they could be strategic as long as they defined the most relevant programs; indicators of projects, if they measured the reach of specific actions; management indicators, when they measured the quality of the administrative processes and services; and indicators of services, if they measured the delivery of the organization's products. The indicators would provide a comprehensive image regarding output in different areas. ${ }^{22}$ During the first phase of developing such indicators, the MBTP tried to connect the performance indicators with the strategic and marketing plan in such a way that a direct link was established from the mission and vision towards individual indicators of performances.

In the second phase of the development of performance indicators, the мвтр hired a Consulting firm -Price Waterhouse Coopers- in order

${ }^{18}$ ST, MBTP, Marketing Plan.

${ }^{19}$ ST, MBTP, Strategic Plan.

${ }^{20}$ ST, MBTP, Performance Evaluation System. Strategic indicators.

${ }^{21}$ Interview, мвтр, Director of Development Indicators.

${ }^{22}$ Ministry of Tourism, mвтP (2000). Recognition of the Quality and Innovation in Public Administration. Innovation of the general process of national and international tourism promotion through the incorporation of a majority state-owned company called Consejo Mexicano de Promoción Turística, s.A. de c.v. Detailed Report, June. 
to establish the Performance Measurement System, and at the same time to serve as an advisor in information technology systems. It was proposed to link the information technology and measurement systems. The assumption was that the former set of indicators focused on financial operations based on countable requirements. Yet, this new performance system tried to address the internal and external necessities in a more concrete way. ${ }^{23}$

The consultant firm recognized that the effectiveness of the system relied on the involvement of top management. It was expected that the indicators would function as long as a commitment by those at the top was established. The underlying assumption was that the indicators that measured individual and organizational performance served as guides for strategic level decision-making. Such a system served three general objectives $;{ }^{24}$ the first was to translate the business strategies into indicators in order to develop and establish clear objectives; the assumption was that once the indicators were identified, a common approach would be applied and put into practice. The second objective was to provide an instrument for continuous feedback in order to evaluate the business strategies. A third objective was to create a common language for internal benchmarking as well as a clearer vision of the Board. Finally, in order to adjust to a new situation it was decided to design a Balanced Scorecard to monitor the capacities of the organization along four dimensions: ${ }^{25}$ i.e. to assess the Board from a financial perspective, from a customer perspective, from an internal business perspective, and from a learning perspective (Kaplan and Norton, 1992).

\section{Critical conditions of policy learning}

The мвтр case stands out as an example of policy learning. It illustrates how the Mexican Ministry of Tourism adopted an organizational model for tourist promotion which had been previously developed by a number of other countries such as Spain, France, Great Britain, Ireland and Canada. To a large extent the case unfolded in accordance with the analytical stages Richard Rose has recommended for lesson-drawing. The process contained elements of searching for relevant policy programs to imitate, it entailed an effort to abstract a cause effect model on the basis of available evidence, comparing different national policies, and an organization was designed in order to take care of the lessons learned from international experiences. Nonetheless, the way the мвтр has developed

\footnotetext{
${ }^{23}$ Interview, мвтP, Director of Development Indicators.

${ }^{24}$ MBTP, PWC (2000), Definition of Performance Evaluation System.

25 These dimensions were financial results, client and market, internal processes and people.
} 
demonstrates that, when implemented, the selected organizational model had to adapt to the specific institutional environments of Mexico: i.e. the regulative, normative and cognitive components that make up the main institutions of Mexican society in general, and its public sector in particular. This process of adaptation may be interpreted as an organizational learning process where its members gradually develop standardized ways of dealing with their tasks.

\subsection{The regulative environments}

Firstly, we observed that the Mexican legal system had a strong impact upon how the MвтP came to function. Its legal form as a majority statecontrolled, limited company entailed that the Board had one foot in the private sector and the other in the public sector. This had significant implications for the kind of regulations it had to observe, and created some difficulties in the operations of the Board. On the one hand, it had to observe the laws that controlled the activities of private companies of limited liability, such as the General Corporation and Partnership Law and the Commercial Code. Since these laws were made to regulate companies aimed at generating revenues and profits, the legal framework provided greater opportunities and flexibility to cope with the market demands. For instance, private companies have freedom to design their own statutes, and appoint their members of the board of administration and executive officers. Under this legal status restrictions are more related to the faculties and powers delegated to the administrators to avoid crimes and felonies.

On the other hand the мвтр also became subject to the rules and guidelines that govern the public sector in Mexico, these include not only the Organic Law of Federal Public Administration and the Federal Law of State-owned companies, but also all the regulations and guidelines provided by the Ministries of Finance and Comptrollership. In addition managers of the Board were also regulated by the Federal Law for Public Servants, which restricts their behavior. For example every year highlevel officials need to submit information about their income and properties, and they are not allowed to hire relatives. The fact that objectives and goals for public agencies differ from those for the private sector means that public organizations are heavily regulated in terms of what they can do. This implies that the MвтP is more controlled, for example the Ministries of Finance and Comptrollership have constantly audited its income and expenditures.

An implication of the legal environments of MBTP seems to be that a certain degree of operational autonomy was lost. From the study of in- 
ternational experiences in this area it emerged that in order to become successful the tourist boards in question would need flexibility and autonomy. The Mexican legal environments however, in particular those of the public sector, seems to have created more dependency than that desirable on the basis of the international experience.

\subsection{The normative environments}

The normative environments refer to how predominant values and norms impose constraints on social behavior (Scott, 2001: 54-56). They specify standards for what is socially desirable and how things should be done. As opposed to the regulative environments values and norms are not legally sanctioned, nevertheless we expect them to influence organizational behavior. The case of the MBTP reveals that the implementation of the best practices from successful organizations has to face old forms of leadership more oriented towards personal relationships, and the structures stand out as more bureaucratic and clientelistic. Political involvement at the Ministry level was fundamental for establishing the Board.

Our examination of the MBTP illustrates how the weak frontiers between the public and private sectors could affect the learning dynamics. To a certain extent, norms and principles that permeate Mexican culture, which are socially accepted, such as patrimonialism, influence its daily operation. Political centralization and the use of symbols denoted a high degree of power distance among members of the Board, such as the use of titles and formalities during interactions. The centralization and power distance that appeared at the federal level seem to have had an impact on decision-making processes, in such a way that all strategic and critical decisions were made at the upper levels of the Board. In accordance with Arellano and Guerrero (2000), public administration in Mexico has been a place for clientelistic representation, competition among elite networks, and an arena where political resources continuously are negotiated and re-negotiated. The MBTP seemed to follow a similar patter, and despite the fact that the General Assembly consist of a variety of actors from both private and public sector, recruitment for the majority of high level positions, including the General Director, depends on a presidential decision, or at least a ministerial appointment, which implies that personal connections count.

With regard to organization, one of the main dilemmas consisted, precisely, in introducing more flexible and autonomous structures in a national culture where power distance and differentiation traditionally have been high (Hofstede, 1991). Flexible structures that promote equality should replace hierarchical structures that reinforce differences and 
uncritical compliance to the established chain of command. And models that encourage innovation and frequent exploration of new routines should supplant the rule orientation and uncertainty avoidance characteristic of Mexican public administration.

Patrimonalism and power distance influenced how the Ministry of Finance and the Comptroller's General Office and the Administrative Development Department provided the framework for constructing of performance indicators. Hence members of the Board tended to comply with the establishment of performance indicators more, because it was ordered by the boss or by an agency that was considered superior, rather than because they recognized the advantages of establishing said evaluation system.

\subsection{The cognitive environments}

From a third perspective the cultural-cognitive components of the institutional environments denote how a shared set of concepts gives meaning to social phenomena. These are the taken-for-granted categories that the members of a society use to interpret social processes and relationships. They are, in the words of Mary Douglas, "the cognitive containers in which social interests are defined and classified, argued, negotiated, and fought out" (cited in Scott 2001: 37). Thus, the social interpretation of what a politician or a civil servant is will differ from one national context to another.

The case of the MBTP suggests that policy-makers are learning not only from environments characterized by their dynamism and complexity such as the tourism sector, but also from international movements and fashions such as New Public Management. Among members of the Board and implementers within the Ministry of Tourism existed a shared understanding of the goodness of private sector management techniques, and the advantages of NPM were to a large extent taken for granted. The extensive perception of crisis in the public sector of Mexico seemed to favor an exploration of alternatives to the existing organizational models, and it served to legitimize the introduction of an agencification model and NPM techniques. For example, the pressure to achieve greater efficiency in the use of public resources, and the citizens' demands for better quality of public services, led to the modification and change of previous practices. The introduction of performance indicators to define activities and measure success and failure, as a part of NPM, required the assistance of external organizations to provide information and advice.

Planning, innovation and objectives were linked in order to adopt NPM principles techniques. Yet, the learning processes of the Board had 
to cope with a tension between the formulations of rational and logic strategies, and the response to the complex and dynamic environment. Moreover, the members of the Board faced the dilemma of introducing NPM techniques characterized by a rational and individualistic approach in a more collective society (Hofstede, 1991). The challenge consisted in finding a balance between a national culture characterized by a persuasive sense of authority and formalized behavior that rewards loyalty to the political group on the one hand, and on the other values which promoted greater autonomy, flexibility and freedom to managers.

Perhaps one of the most contested and demanding aspects of NPM has been the introduction of mechanisms that allow measuring success (Minogue et al., 2001) and may take many forms to produce systems of performance indicators that vary in their speed and comprehensiveness (Carter et al., 1995). In the case of the MBTP, the development strategies for learning were translated in two ways: firstly, as the capacity and disposition to search for new ideas and experiment with new alternatives, and secondly, as the creation of knowledge that enabled the Board to face changing and complex conditions in the environment. Nevertheless, the development of a system of indicators appeared more like a way of controlling the activities and functioning of the Board from the upper levels of the federal public administration, instead of being a source of knowledge for members of the Board.

Law traditions seemed to have an impact on the founding and functioning of the Board. These traditions represent a shared vision of the word and what should be the role of individuals and the government. In contrast with the common law tradition -where NPM arise-, the civil law tradition immersed in the Mexican legal system not only makes a clear separation between the private and public law, but also infuses public servants with common values and expectations, such as risk avoidance. Similar to other public agencies the decision-making process at мвтP tended to be formalized and centralized; it was expected that members of the Board should perform their routines as managers; nonetheless, at the same time they had to act as public officials permeated with historical legacies drawn from the Mexican culture.

\section{General considerations}

By and large, our case study of MBTP illustrates three basics features: Firstly, the regulative, normative and cognitive pillars seem to reinforce each other and operate at different levels when a policy lesson is implemented. Secondly, the two theoretical perspectives we have applied -policy transfer and the three institutional pillars- may address different 
problems. And thirdly, it is difficult to establish a clear distinction between the three institutional dimensions when it comes to operationalize the variables.

The Mexican experience reveals that the normative dimension primarily tends to manifest itself at the individual level, e.g. when patriomonialism and clientelism influence the leadership style of the мвтр, or result in a more centralized decision-making process. At a collective level we observe how the regulative dimension has an impact on the formal setup of the Board and its relations with other agencies. This kind of impact comes from the General Constitution, as well as from the legal framework that controls both private and public sector organizations. Finally, the cognitive pillar appears to have more influence at the organizational level, where shared meanings about efficiency and superiority of private sector seemed to influence the design and implementation of NPM techniques, as well some sort of basic principles of Mexican public agencies. In general terms, this seems to be similar to the path dependency approaches, in which norms and values from the origins of an organization will have great importance in its future development (Christensen et al., 2007: 45).

Additionally, it is important to notice that in some experiences the institutional design of this type of agencies has created more dilemmas than solutions; for example on the one hand, in terms of the balance between the control exercised by politicians and the necessary managerial autonomy (Richards and Smith, 2006); and on the other, in the potential tension between transparency and accountability versus technical decisions.

This article has discussed some elements of the learning processes associated with establishing a new public agency in Mexico. We have only focused on a limited number of aspects. Yet, we hope that these ideas may contribute to further research in the complex dynamics of organizational change and critical conditions of learning in transforming societies. For instance, we expect a richer dialogue with other approaches, such as those who see the reform processes as a part of a wider institutional context, where political actors are driven more by a logic of appropriateness and organizations are conceived as institutions rather than structural and malleable instruments (Brunsson and Olsen, 1993; Egeberg and Laegreid, 1999). We also want the article to open the door for a better understanding of how institutional environments may influence the outcome of donor-supported reforms in such societies. 


\section{References}

Aldrich, Howard (1999), Organizations Evolving, Sage, Thousands Oaks, CA.

Arellano, David and Juan Pablo Guerrero (2000), "Stalled Administrative Reforms of the Mexican State", Working Paper No. 88, CIDE, Mexico.

Askvik, Steinar and Inge Tveten (2000), Twinning as strategy for institution building. Norwegian Experiences, University of Bergen, Bergen.

Brower, Ralph, Miychell Abolagia and Jered Carr (2001), "On improving Qualitative Methods in Public Administration Research”, Administration and Society, 32 (1), Sage, Virginia Tech University, pp. 102-120.

Brunsson, Nils and Joha P. Olsen (1993), The Reforming Organization, Fagbokforlaget, Bergen.

Carter, Neil, Rudolf Klein and Patricial Day (1995), How Organizations Measure Success. The Use of Performance Indicators in Government, Routledge, London.

Christensen, Tom and P Lægreid (2001), NPM. The transformation of Ideas and Practice, Ashgate Publishing, Aldershot.

Christensen, Tom (2008), "The Development of Public Institutions Reconsidering the Role of Leadership", Administration \& Society, 40 (3), Sage, Virginia Tech University, pp. 271-297.

Christensen, Tom and Per Lægreid (2007), Transcending New Public Management: The Transformation of Public Sector Reforms. Ashgate Publishing, Aldershot.

Christensen, Tom, Per Laegreid, Paul G. Roness and Kjell Arne Rovik (2007), Organization Theory and the public sector. Instrument, culture and Myth, Routledge, London.

Cresswell, John (1994), Research Design. Qualitative and Quantitative Approaches, Sage, Thousand Oaks. 
Dolowitz, David and David Marsh (2000), "Learning from Abroad: The Role of Policy Transfer in Contemporary Policy-Making", Governance: An International Journal of Policy Administration, 13 (1), International Political Science Association's Research Committee on the Structure \& Organization of Government (sog), pp. 5-24.

Egeberg, Morten and Per Laegreid (1999), Organizing Political Institutions, Scandinavian University Press, Oslo.

Guba, Egon and Yvonna Linconl (1994), "Competing paradigms in Qualitative Research" in Norman Denzin, Norman and Ivonna Lincoln, Handbook of Qualitative Research, Sage, London.

Haunschild, Pamela and David Chandler (2008), "Institutional-level learning: Learning as source of institutional change", in Royston Greenwodd, Sahnlin-Andersson, Kerstin Chistine Oliver and Roy Suddaby. The Sage handbook of organizational institutionalism, Sage, London, pp. 624-649.

Heclo, Hugh (2006), "Thinking Institutionally", in R. A. Rhodes W. Sarah Binder and Bert Rockman, The Oxford Handbook of political institutions, Oxford University Press, New York, pp. 731-742.

Hinings, C. R. and Pamela Tolbert (2008), "Organizational Institutionalism and Sociology: A Reflection", in Royston Greenwod, Kerstin Sablin Anderson, Christine Oliver and Roy Suddaby, The Sage handbook of organizational institutionalism, Sage, London, pp. 473-492.

Hodge, Graeme and Carsten Greve (2007), "Public-Private Partnerships: An International Review of Performance", Public Administration Review, June.

Hofstede, Geert (1991), Cultures and Organizations. Software of the Mind, McGraw-Hill, London.

Hollis, Martin (1999), The philosophy of social science. An introduction, Cambridge University Press, Cambridge.

Kaplan, S. Robert and David P. Norton (1992), "The Balance Scorecard -measures that drive performance", Harvard Business Review, 70 (1), Harvard Bussiness School, Masachusets, pp. 71-79. 
Laegreid, Per and Paul Roness (1998), Administrative Reform programmes and institutional response in Norwegian Central Government, University of Bergen, Bergen.

Leicht, Kevin and Mary Fenner (2008), "Institutionalism and the Professions", in R. Greenwodd et al., The Sage handbook of organizational institutionalism, Sage, London, pp. 431-448.

Little, Daniel (1991), Varieties of social explanation. An introduction to the philosophy of social science, West View Press, Colorado.

March, James and Johan P. Olsen (2006), "Elaborating the New Institutionalism", in R. Rhodes et al., The Oxford Handbook of political institutions, Oxford University Press, New York, pp. 3-22.

Minogue, Martin and Willy McCourt (2001), The internationalization of New Public Management, Cheltenham, Edwar Elgar.

Peters, Guy (1999), "Institutional Theory and administrative reform", in M. Egeberg and P. Laegreid (eds.), Organizing Political Institutions, Scandinavian University Press, Oslo.

Powell, Walter and Jeanette Colvas (2008), "Microfoundations of Institutional Theory", en R. Greenwodd et al., The Sage handbook of organizational institutionalism, Sage, London, pp. 276-298.

Ragin, Charles (1997), "Casing and the process of social inquiry", in C. Ragin and H. Becker S. (eds.), What is a case. Exploring the foundations of social inquiry, Cambridge University Press, New York, pp. 217-226.

Ragin, Charles and Howard Saul Becker (eds.) (1992), What is a Case? Exploring the foundations of social inquiry, Cambridge University Press, New York.

Richards, David and Martin Smith (2006), "The Tensions of Political Control and Administrative Autonomy: From NPM to a Reconstituted Westminster Model" in Tom Christensen and Per Laegreid (eds.), Autonomy and Regulation. Coping with Agencies in the Modern State, Cheltenham, UK, Edward Elgar Publishing. 
Roness, Paul (2007), "Types of State Organizations. Arguments, doctrines and changes beyond NPM", in Tom Christensen and Per Lægreid (eds.), Transcending New Public Management: The Transformation of Public Sector Reforms, Ashgate Publishing, Aldershot.

Rose, Richard (1993), Lesson-Drawing in Public Policy: A guide to a learning across time and Space, Chatham House, New Jersey.

Scott, W. Richard (2001), Institutions and Organizations, Sage, Thousands Oaks, CA.

Stinchcombe, Arthur (1965), "Social Structure and Organizations", in J. March (ed.), Handbook of Organizations, Rand McNally, Chicago, pp.142-193.

Walton, John (1997), "Making the Theoretical Case", in C. Ragin and H. Becker (eds.), What is a case. Exploring the foundations of social inquiry, Cambridge University Press, New York, pp. 121-138.

Wieviorka, Michel (1997), "Case studies: history or sociology", in C. Ragin and H. Becker (eds.), What is a case. Exploring the foundations of social inquiry, Cambridge University Press, New York, pp. 121-138.

\section{Governmental references}

- Federal executive branch; Program for the modernization of federal public administration; summary.

- Federal executive branch; Program for the modernization of federal public administration.

- Federal executive branch; 1995-2000 National Development Plan.

- Federal executive branch (1997); national program to finance development. Setting the path for sustainable growth, June.

- Mexican Board of Tourist Promotion. Price Water House (2000), Definición del Sistema de Medición del Desempeño. 
- Mexican Board of Tourist Promotion. Price Water House (2000), Determinación del Sistema de Administración del Desempeño, Inforrme final, julio.

- Ministry of Tourism (2000), External diagnosis.

- Ministry of Tourism (2001), Impact of New Technologies of the Mexican Tourism.

- Ministry of Tourism (1999), Promap, Sectur, Presentación de Avances, agosto.

- Ministry of Tourism (2000), "Sectur drive tourism development", Press release, 9, June.

- Ministry of Tourism (2000), "Tourism is one of the main three sources of foreign currency income providers in Mexico", Press release, 15 , June.

- Ministry of Tourism (2000) Tourism Executive Commission informs about important advances of the sector during the fourteenth Cork meeting. Press release. 7, June.

- Ministry of Tourism, MBTP, Mexican Board of Tourist Promotion in Mexico, General Information, Brochure.

- Ministry of Tourism, мвтр (2000), Memoria de Labores, octubre 1999 a octubre 2000 .

- Ministry of Tourism, мвтр, Manual de Inducción.

- Ministry of Tourism, MBTP, Plan de Mercadotecnia.

- Ministry of Tourism, MвTP, Plan Estratégico.

- Ministry of Tourism, mbtp, Sistema de Evaluación del Desempeño. Indicadores estratégicos.

- Ministry of Tourism, mвтP, Estrategias y Líneas de Acción.

- Ministry of Tourism, мвтр, Tourism in Mexico. 
- Ministry of Tourism, MвтP, Programa Institucional 1991-2001.

- Ministry of Tourism (1999), Oficialía Mayor, Informe de labores 19981999 y perspectivas para el año 2000, diciembre.

- Ministry of Tourism, mbTp (2000), Innovación del proceso general de promoción turística nacional e internacional a través de la conformación de una empresa de participación estatal mayoritaria denominada Consejo Mexicano de Promoción Turística, s.a de c.v. Reporte inicial, mayo.

- Ministry of Tourism, mbtr (2000), Reconocimiento a la Calidad y la Innovación en la Administración Pública. Innovación del proceso general de promoción turística nacional e internacional a través de la conformación de una empresa de participación estatal mayoritaria denominada Consejo Mexicano de Promoción Turística, s.A. de c.v. Reporte detallado, junio.

Recibido: 19 de junio de 2007.

Reenviado: 2 de julio de 2009. Aceptado: 10 de septiembre de 2009.

Jorge E. Culebro-Moreno, Metropolitan Autonomous University. Cuajimalpa. Mexico, Department of Institutional Studies, Professor. Dr. Polit. (Doctor Raerum Politcarum), University of Bergen, Norway, Department of Administration and Organization Theory, Research areas: Institutional theory, administrative reform, policy transfer, regulation and regulatory agencies, Aprendizaje y Reforma Administrativa en México. (2008) Editorial Juan Pablos-uam, México, Atomización del Estado y nuevas formas de control: la introducción de los Convenios de Desempeño en Organizaciones Públicas", in Gestión y Política Pública, Vol. xvir, Numero 1, Primer Semestre 2008, "Aportaciones del Nuevo Institucionalismo Económico y Normativo a los Acuerdos de Paz". Universidad Iberoamericana. Co-author: Laura Zamudio. Working Paper. (2006) 40 pages, "La Nueva Gestión Pública. Hacia Gobiernos Iguales o Diferentes en el Mundo." GESPyE Gestión Pública y Empresarial. No. 8 Article in a journal (2006). Guadalajara, México, Learning and Administrative Reform. The introduction of New Public Management in the Mexican Federal Public Administration. Report no. 8 (2004) University of Bergen. 374 pages. 
Steinar Askvik, University of Bergen, Department of Administration and Organization Theory; Professor, University of Bergen, Norway, Department of Administration and Organization Theory. Research areas: Organizational Learning, organizations and leadership, and planned institutions building, Book: Trust in public institutions in South Africa I edited by Steinar Askvik, Nelleke Bak (2005) Aldershot: Ashgate. 268 pages. Book: EFA and the challenge of administrative competence building I Steinar Askvik, Marit Tjomsland, Bergen: Centre for Development Studies, University of Bergen. 80 pages. (2005) "La Gerencia y el aprendizaje organizacional”, in Gestión y Política Pública. CIDE. Vol, viII, num 2. 1999, pages. 249-273. 